\title{
Acceptance of Mobile Banking Services in Makassar: A Technology Acceptance Model (TAM) Approach
}

\author{
Abdul Razak Munir ${ }^{1}$, M.S. Idrus ${ }^{2}$, A. Rahman Kadir ${ }^{1}$, Jusni $^{1}$ \\ ${ }^{1}$ Faculty of Economics and Business, Hasanuddin University, Makassar, Indonesia \\ ${ }^{2}$ Faculty of Economics and Business, Brawijaya University, Malang, Indonesia
}

\begin{abstract}
Mobile banking services is a relatively new banking services. This study aims to look customer acceptance of mobile banking services in Makassar and the influencing factors using the Technology Acceptance Model (TAM) framework. The design of this study is causal and descriptive with sample of 180 customers selected by convenience and accidental sampling. Data were collected through structured interviews with a questionnaire. The results showed that (1) Perceived Ease of Use significantly influence Perceived Usefulness; (2) Perceived Ease of Use significantly influence Intention to use and (3) Perceived of Usefulness significantly influence intention to use. The research concluded that to increase customer acceptance or adoption of mobile banking services, the banks should pay attention to and highlight factors Perceived Usefulness and Perceived Ease of Use.
\end{abstract}

Keywords - Perceived Ease of Use, Perceived Usefulness, Intention to use, Mobile Banking, TAM

\section{INTRODUCTION}

In recent decades, the influence of ICT could not be denied in the business and government segments. Information and communication technologies facilitate and establish individual daily by offering services such as e-commerce, e-government, e-learning, e-health and e-working [1]. Mobile banking is a result of the development of mobile technology used in the commercial domain. Mobile banking combines information technology and business applications together. Thanks to the mobile banking, customers can use it to get banking services 24 hours a day without having to visit a bank branch for personal transactions. Mobile banking is a relatively new service offered by banks to customers, and because of the convenience and features that save time and customers appreciate the services [2].

Compared to other e-banking services, the development of mobile banking (m-banking) regarded the fastest. This development is due to the presence of $\mathrm{m}$-banking services to answer the needs of a modern society that is promoting mobility. With one touch, creates convenience m-banking banking services in one hand. Benefit of mobile banking services will increase customer satisfaction. Furthermore, mobile banking creates "value" for the bank as a customer transaction service delivery channel access (wireless).

The rapid advanced of technology in banking technologies, especially in the banking industry, force players to re-formulate the information technology strategies that they employ to remain competitive. Customers now want something more than just banking services. Customers want the convenience and flexibility $[3,4]$ on products and services that suit their needs and easy to use which cannot be offered by traditional banks. In the future of e-banking will be an important strategic application to compete that must be offered by all banks and financial institutions.

Transaction in the branch is still the most common method used for bank transactions in Makassar as well as in other cities. However, mobile technologies and internet technologies are rapidly changing the design and delivery of financial services. Today almost all banks in Makassar have introduced mobile banking system to improve operations and reduce transaction costs. In spite of all efforts aimed at developing a better and easier mobile banking system, mobile banking is generally less noticed and utilized by the customer. Therefore we need an understanding of customers' acceptance of mobile banking and needs to identify factors that could affect customer acceptance for use of mobile banking. The issue is important because the answer to this research will provide clues that will help the banking industry to formulate their marketing strategies to promote new forms of mobile banking in the future.

The variables in this study come from the framework of the Technology Acceptance Model (TAM) developed by Davis, et. al [5]. These variables consist of: Perceived Ease of Use (PEOU), Perceived Usefulness (PU) and Intention to use (IU). Perceived Ease of Use (PEOU) is the belief that the person using the system will be free of effort. The perceived usefulness (PU) is the level at which a person believed that the use of the system will be able to improve its performance. Intention to use (IU) is defined as a force of one's attention to use something.

It is important to research the factors that make consumers behavioral intention toward this technology. Previous similar studies are still few and especially no one has done in Makassar. Base these conditions; this 
study aims to analyze the factors that influence the acceptance of mobile banking customers in the city of Makassar.

\section{RESEARCH PROBLEM} follows:

Based on previous background, the main issues to be examined in this study can be formulated as

1. Is Perceived Ease of Use have positive influence on Perceived Usefulness of Mobil Banking Customer?

2. Is Perceived Ease of Use have positive influence on Intention to Use of Mobil Banking Customer?

3. Is Perceived Usefulness have positive influence on Intention to Use of Mobil Banking Customer?

\section{LITERATURE REVIEW}

\section{Technology Acceptance Model (TAM)}

TAM introduced by Davis on 1989[5]. At that time the emphasis on reaching and effectively identify the factors that have an impact on user acceptance of information technology, There is a lack of the right model for user adoption of IT because all the models at that time was not valid or their relationship with user not verified [5]. A decade after the entry of TAM into the System Information adoption model, TAM has been accepted as a powerful model, widely accepted and continues used in the area of IT adoption measurement [6].

Davis [5] and Davis et al. [7] states that TAM is the appropriate model to explain reasons why user accept or reject Information technology. TAM was developed based on Theory of Reasoned Action [8, 9] and Theory of Planned Behavior [10]. TRA based on assumption that people consider the possible impact of their action and take decision to act based on their reasoning [9]. TAM consist of two main factors; perceived ease of use and perceived usefulness.

Davis identifies two factors; perceived ease of use (PEOU) and perceived usefulness (PU) as effective factor which influenced people behavior when use Information Technology with reliability of 0.98 and 0.94 . Davis [5] found both two factors have strong relationship with actual usage of information technology now and on the future. But Davis concludes that PU has stronger relation with usage of computer technology compare with PEOU. Farther, Davis finding indicates that easiness in a system usage has impact on user perception about usefulness a system.

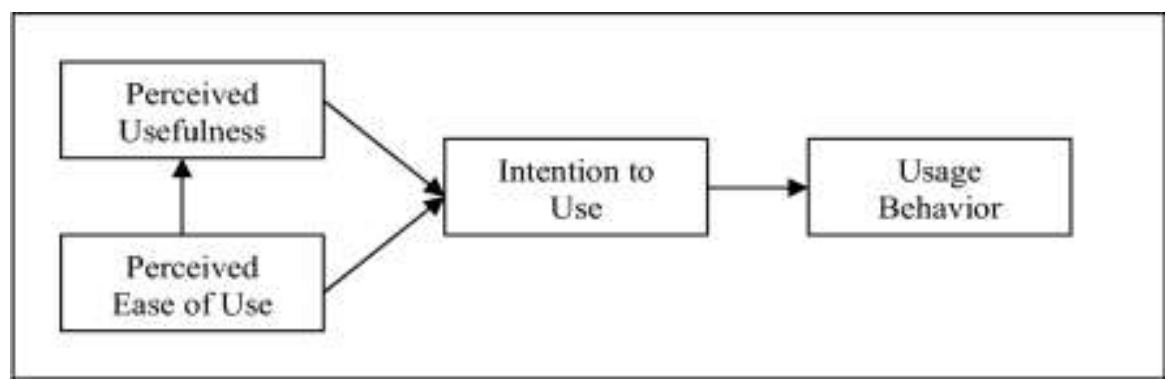

Figure 1. Technology Acceptance Model

\section{Perceived Usefulness (PU)}

PU define as usefulness a system a seen by user and states that user will keep use that system until they find it useless anymore. Davis defines PU as - level where someone believes that using a system will increase their performance. PU identified as a part of important factor which has influence on intention to use of Information Technology. This issue very emphasized by most researchers which attempt to find factors that lead to adoption of Information technology $[11,7,12,13,14,15,16,17,18,19,20]$.

\section{Perceived Ease of Use (PEOU):}

PEOU defines as - level where someone believes that using particular system will free from efforts. Difficulties in using particular system sometimes overcome benefit a system and this issue explain impact of PEOU on PU because easy to use seems more useful and vice versa [5]. According to many scholars [11, 5, 13, $14,16,19,20]$, PEOU has direct influence on intention to use Information Technology.

On their research $[21,22,23,24,25,26,27]$ have examined influence of PEOU and PU in various environment and different organization and all of them conclude that factors are valid and reliable and have impact on information technology uses. TAM has been examined and accepted by many researchers as useful and reliable model for acceptance and adoption of information system [5, 7, 15, 21, 24, 28]. Moreover this model evolved with many changes which added by many researches $[29,30,31,32]$. For example, Venkatesh 
and Davis [29] introduce extension of TAM model which explain factor from cognitive instrumental process and social influences have impact on PU and intention to use information system.

\section{HYPOTHESIS BUILDING}

Wu and Wang [33] state that Perceived ease of use influence Perceived usefulness mobile commerce. Gu et al [34] states better Perceived ease of use will lead to better Perceived usefulness mobile banking. Prior research proved significant impact of perceived of use on behavioral intention directly and indirectly through effect of perceived usefulness [27, 35, 36, 37, 38, 33]. Same findings by [39, 40, 41, 29] states there is direct influence from ease of use on usefulness.

H1: Perceived ease of use influence significantly Perceived usefulness customer of mobile banking in Makassar

Many prior researches have proved significant impact of perceived of use on intention to use, directly and indirectly [42, 43, 44, 45, 29]. On beginning of 1962 Rogers said that understanding technology ending on product adoption or innovative service which known by customer as ease of use. Next, Chen and Barnes [46] found that two technology aspects from interface which known as perceived ease of use and perceived usefulness significantly influence customer intention to adopt.

H2: Perceived ease of use influence significantly Intention to use customer of mobile banking in Makassar

The importance of perceived usefulness has recognized widely in e-banking field [43, 44, 47, 48, 49]. There are many researchers proves significant impact of perceived usefulness on intention to adopt $[46,43,44$, $12,29,50]$. Tan and Teo [51] states that perceived usefulness is one important factor which determines adoption of an innovation.

H3: Perceived usefulness influence significantly Perceived usefulness customer of mobile banking in Makassar

\section{Research Location}

\section{RESEARCH METHOD}

The research was conducted in Makassar City considering that it is the center of economic activity which also central of banking activities in South Sulawesi. This type of research is explanatory research were conducted to examine the effect of the variables were hypothezed before [52] and using the structural equation model that aims to test the measurement model and structural models $[53,54]$ by using a questionnaire and the data are cross-sectional data.

\section{Design and Research Variable}

Scientific research is basically an attempt to reveal the nature of physical phenomena in a systematic, controlled, empirical and critical [55]. If translated into statistics, the definition of research is an attempt to reveal the relationship between variables [56].

In this research will be used forms of descriptive and causal verification. Descriptive study conducted to get an overview of the characteristics of the study respondents. Meanwhile verification studies aim to determine the relationship between the study variables through hypothesis testing using statistical calculations [57].

The variables in this study come from the framework of the Technology Acceptance Model (TAM) developed by Davis, et. al [7]. These variables consist of: Perceived Ease of Use (PEOU), Perceived Usefulness (PU) and Intention to use (IU). Perceived Ease of Use (PEOU) is the belief that the person using the system will be free of effort. The perceived usefulness (PU) is the level at which a person believed that the use of the system will be able to improve its performance. Intention to use (IU) is defined as a force of one's attention to use something.

Mobile banking is a form of electronic banking services offered through mobile and banks are connected through the internet database where clients can conduct and transact financial services in an artificial environment (virtual environment). A bank decided to invest in information systems such as the Internet and mobile banking for several reasons, such as cost savings, improved quality of products and services, and to produce more without increasing costs. The attitude of the customers towards the adoption or acceptance of a new information system has serious implications for the success of the system [5, 29]. If the customer is not willing to accept or adopt the new system, the system will not provide the maximum benefit for the bank. The more the customers accept the new system, customers are increasingly willing to make changes in the practice and use of time and effort to start using the new information system [58].

\section{Population and Sample}

Population in this research are the entire mobile banking users in the Makassar. Considerations for selecting Makassar base on a survey by Yahoo Inc (2010), which set Makassar is the third after Bandung and Semarang, which has the most mobile Internet users in Indonesia. 
It is not known the exact number of the user's Mobile Banking in Makassar related with the "secrecy" banks, therefore to specify minimum sample criteria in this research follow the rule of thumb in the SEM analysis, i.e between 150 to 200 people [59], then as many as 180 samples were selected using purposive sampling technique, the sampling techniques that are tailored to the needs of the research. Distributing questionnaires in this study conducted by accidental sampling which is doing research to meet directly with the respondent. Respondents will be found in some of the banks that have been providing mobile banking facility following completion of their banking transactions.

\section{Data Collection.}

The data was collected using direct interviews and pre-tested questionnaire. Demographic data and data research variables collected by interviews using questionnaires.

\section{Data Analysis.}

Test of validity is done by using confirmatory factor analysis that will generate factor loading score of each latent variable indicator. Factor loading score greater than 0.50 [59] is used as a cut-off value validity of the construct indicators.

Reliability tests performed using the construct reliability and Variance Extracted for each latent variable. The Value of Construct reliability which greater than 0.70 [59] and VE value greater than 0.50 [60] were used as a cut-off value of reliability. To measure causality between variables study through structural equation modeling, software AMOS version 20 was used meanwhile characteristic of the respondents were processed using IBM SPSS software version 20.

\section{Sample Characteristics}

\section{RESEARCH RESULT}

Table 1 show most of the sample were Male respondents. This shows that in the case of banking and mobile banking, men are still more dominant in decision-making. This is in the line with the opinion of Lamb et.al [61] stated men and women consumers differ in their needs, while Kotler and Armstrong [62] stated that gender and culture are characteristic of consumers who provide stimuli for consumers to decide on the purchase a product or service offered.

Table 1. Demographic Characteristic of Respondent

\begin{tabular}{|c|c|c|c|c|c|}
\hline \multirow[b]{2}{*}{ Age } & \multicolumn{4}{|c|}{ S e $x$} & \multirow[b]{2}{*}{ Total } \\
\hline & Male & $\%$ & Female & $\%$ & \\
\hline $18-<25$ year & 12 & $6.67 \%$ & 18 & $10.00 \%$ & 30 \\
\hline $25-<35$ year & 60 & $33.33 \%$ & 30 & $16.67 \%$ & 90 \\
\hline $35-<45$ year & 24 & $13.33 \%$ & 18 & $10.00 \%$ & 42 \\
\hline$>45$ year & 18 & $10.00 \%$ & 0 & $0.00 \%$ & 18 \\
\hline Total & 114 & $63.33 \%$ & 66 & $36.67 \%$ & 180 \\
\hline \multicolumn{6}{|l|}{ Occupation } \\
\hline Student & 18 & $10.00 \%$ & 36 & $20.00 \%$ & 54 \\
\hline Civil Employee & 24 & $13.33 \%$ & 18 & $10.00 \%$ & 42 \\
\hline Public Employee & 24 & $13.33 \%$ & 0 & $0.00 \%$ & 24 \\
\hline Self Employee & 18 & $10.00 \%$ & 6 & $3.33 \%$ & 24 \\
\hline Professional & 6 & $3.33 \%$ & 0 & $0.00 \%$ & 6 \\
\hline Other & 24 & $13.33 \%$ & 6 & $3.33 \%$ & 30 \\
\hline Total & 114 & $63.33 \%$ & 66 & $36.67 \%$ & 180 \\
\hline \multicolumn{6}{|l|}{ Income } \\
\hline$<1$ million & 6 & $3.33 \%$ & 30 & $16.67 \%$ & 36 \\
\hline $1 \mathrm{~m}-<2,5 \mathrm{~m}$ & 24 & $13.33 \%$ & 0 & $0.00 \%$ & 24 \\
\hline $2,5 \mathrm{~m}-<5 \mathrm{~m}$ & 54 & $30.00 \%$ & 24 & $13.33 \%$ & 78 \\
\hline $5 \mathrm{~m}-<7,5 \mathrm{~m}$ & 18 & $10.00 \%$ & 0 & $0.00 \%$ & 18 \\
\hline $7,5 \mathrm{~m}-<10 \mathrm{~m}$ & 6 & $3.33 \%$ & 0 & $0.00 \%$ & 6 \\
\hline$>10 \mathrm{~m}$ & 6 & $3.33 \%$ & 12 & $6.67 \%$ & 18 \\
\hline Total & 114 & $63.33 \%$ & 66 & $36.67 \%$ & 180 \\
\hline $\begin{array}{l}\text { Relationship with } \\
\text { Bank }\end{array}$ & & & & & \\
\hline
\end{tabular}




\begin{tabular}{|l|r|r|r|r|r|}
\hline$<1$ year & 6 & $3.33 \%$ & 0 & $0.00 \%$ & 6 \\
1 year - <3 year & 0 & $0.00 \%$ & 12 & $6.67 \%$ & 12 \\
3 year - <5 year & 30 & $16.67 \%$ & 6 & $3.33 \%$ & 36 \\
> 5 year & 78 & $43.33 \%$ & 48 & $26.67 \%$ & 126 \\
Total & 114 & $63.33 \%$ & 66 & $36.67 \%$ & 180 \\
\hline Education & & & & & \\
\hline S1 (undergraduate) & 72 & $40.00 \%$ & 48 & $26.67 \%$ & 120 \\
S2 (postgraduate) & 42 & $23.33 \%$ & 18 & $10.00 \%$ & 60 \\
Total & 114 & $63.33 \%$ & 66 & $36.67 \%$ & 180 \\
\hline
\end{tabular}

Table 1 also shows that the age range is at most age range 25 to 35 years which consisted of 60 male or about $33.33 \%$ and female 30 or about $16.67 \%$, indicating that young age range is more open to the adoption of new things including new technologies. This is in the line with the findings of Wood and Swait [63] study which states certain characteristics of the user can result in certain types of behavior meanwhile Lamb et.al [61] stated, age is a demographic factor associated with consumer buying behavior.

Occupation and big income in that age ranges indirectly have a bigger needs including banking needs [62]. In table 1 is seen that as many as 54 people or $30 \%$ of which consists of as many as 18 men about $10 \%$ and women 36 people about $20 \%$ are students. This is consistent with the fact that the student is having openness to new technologies and technology "mobile" is not a new thing for them. Followed by the work of civil employee, which in reality is most often associated with banking.

Table 1 also shows that the income range between 2.5 million to 5 million per month is the largest group with a total of 78 people or $43.33 \%$ consisting of 54 men, about $30 \%$, and 24 women, about $13 \%$. This group includes middle and upper income groups who actively use mobile banking facility

From Table 1 it shows that most respondents are long time customer on their banks. Approximately 126 people or $70 \%$ of which consists of man as much as 78 people or about $43.33 \%$ and women by 48 people or about $26.67 \%$ are customers of a period of more than 5 (five) years. This suggests that a consumer's loyalty will likely enable them to try other services offered by the company [64].

Table 1 also shows that most the respondents have higher education. This indicates the level of customer awareness and the ability to make choices or at least have the ability to influence those who are more educated to get more services from banking.

\section{Multivariate Results}

From Table 2 shows that all of the indicators used in this study are valid, as seen from the value of the Standardized Loading Factors that all have value above 0.5, which means all the indicators are valid tools to measure the research constructs. Meanwhile value of all Construct reliability above 0.70 Reliability and Variance Extracted values were above the 0.50 showing good reliability of the research constructs.

Table 2. Variable Validity and Reliability

\begin{tabular}{|c|c|c|c|c|c|c|c|}
\hline \multirow{2}{*}{ Variable } & \multirow{2}{*}{ Indicator } & \multirow{2}{*}{$\begin{array}{c}\text { Standardized } \\
\text { Loading Factors }\end{array}$} & \multirow{2}{*}{$\begin{array}{c}\text { Standard } \\
\text { Errors }\end{array}$} & \multirow{2}{*}{$\mathrm{t}$ value } & \multicolumn{2}{|c|}{ Reliability } & \multirow{2}{*}{ Comment } \\
\hline & & & & & $\mathrm{CR}$ & VE & \\
\hline \multirow{4}{*}{$\begin{array}{l}\text { Perceived } \\
\text { Usefulness } \\
\text { (PU) }\end{array}$} & y11 & 0.814 & - & Fix & \multirow[t]{4}{*}{0.88} & \multirow[t]{4}{*}{0.64} & \multirow{4}{*}{$\begin{array}{l}\text { Good Reliability } \\
\text { Good Validity }\end{array}$} \\
\hline & y12 & 0.723 & 0.078 & 9.914 & & & \\
\hline & y13 & 0.833 & 0.073 & 12.470 & & & \\
\hline & y14 & 0.835 & 0.076 & 11.571 & & & \\
\hline \multirow{4}{*}{$\begin{array}{l}\text { Perceived } \\
\text { Ease of Use } \\
\text { (PEOU) }\end{array}$} & $\mathrm{y} 21$ & 0.595 & - & Fix & \multirow[t]{4}{*}{0.80} & \multirow[t]{4}{*}{0.57} & \multirow{4}{*}{$\begin{array}{l}\text { Good Reliability } \\
\text { Good Validity }\end{array}$} \\
\hline & $y 22$ & 0.842 & 0.203 & 7.246 & & & \\
\hline & $y 23$ & 0.727 & 0.180 & 7.067 & & & \\
\hline & y24 & 0.658 & 0.166 & 6.806 & & & \\
\hline \multirow{4}{*}{$\begin{array}{l}\text { Intention to } \\
\text { use } \\
\text { (IU) }\end{array}$} & $\mathrm{y} 31$ & 0.759 & - & Fix & \multirow[t]{4}{*}{0.79} & \multirow[t]{4}{*}{0.50} & \multirow{4}{*}{$\begin{array}{l}\text { Good Reliability } \\
\text { Good Validity }\end{array}$} \\
\hline & $\mathrm{y} 32$ & 0.693 & 0.114 & 9.904 & & & \\
\hline & $\mathrm{y} 33$ & 0.740 & 0.123 & 8.079 & & & \\
\hline & $\mathrm{y} 34$ & 0.606 & 0.115 & 7.291 & & & \\
\hline
\end{tabular}

Figure 1 shows the results of estimation of influence between variables using AMOS software version 20. It can be seen all the criteria Goodness of Fit Indices as follows: Chi-Square expected small which is 56.724, CMIN/DF were below 2 which is 1.112 , insignificant probability which is 0.270 , GFI above .90 which is 0.951 , 
the AGFI above 0.90 which is 0.921 , TLI above 0.90 which is 0.991 and RMSEA below 0.08 which is 0.025 . These criteria show that the data in this study are good fit.

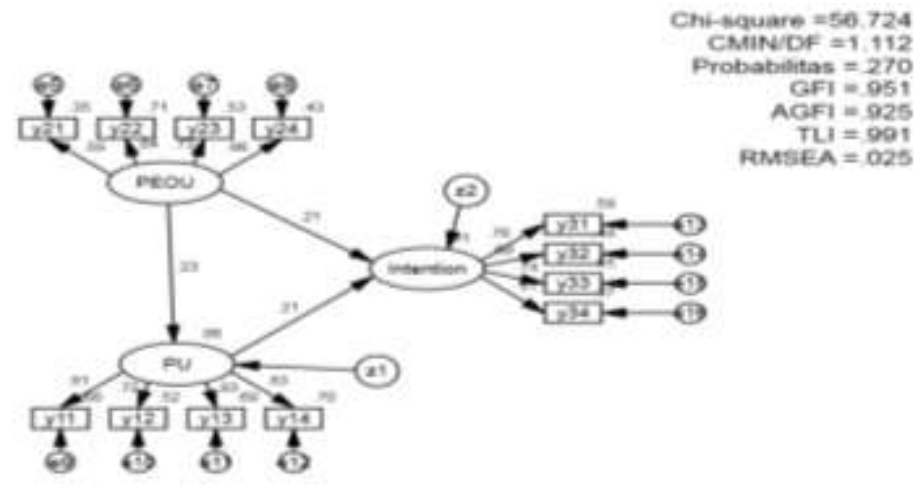

Figure 1 estimation results

Table 3 shows the influence of between variables as follows: The Influence of Perceived Ease of Use (PEOU) on intention to use (IU) is 0.206 significant with probability 0.033 , Influence of Perceived Ease of Use (PEOU) to the Perceived usefulness (PU) is 0.235 significant with probability 0.009 , the Influence of Perceived Usefulness (PU) on intention to use (IU) is 0.207 significant with probability 0023 . Meanwhile the influence of Perceived Ease of Use (PEOU) on Intention to Use (IU) through Perceived Usefulness (PU) is 0.048 which also significant.

Table 3. Influence of between Variable Results.

\begin{tabular}{|ll|r|r|r|r|l|}
\hline & & $\begin{array}{r}\text { Standardized } \\
\text { Regression } \\
\text { Weights }\end{array}$ & S.E. & C.R. & P & Label \\
\hline PU $<---$ & PEOU & .235 & .135 & 2.622 & .009 & par_3 \\
\hline Intention <--- & PEOU & .206 & .115 & 2.133 & .033 & par_1 \\
\hline Intention <--- & PU & .207 & .072 & 2.266 & .023 & par_2 \\
\hline
\end{tabular}

\section{DISCUSSION}

\section{Influence of Perceived Ease of Use on Perceived Usefulness.}

The coefficient of the effect of Perceived Ease of Use (PEOU) on the Perceived usefulness (PU) is 0.235 with probability of 0.009 . That Coefficient indicates that Perceived Ease of Use (PEOU) variable has positive effect on Perceived usefulness (PU). This means that the increase in Perceived Ease of Use (PEOU) will be followed by an increase in Perceived Usefulness (PU), on the contrary, decreased Perceived Ease of Use (PEOU), will be followed by a decline in Perceived Usefulness (PU), assuming other factors held constant. Statistical t-value shows the influence of Perceived Ease of Use (PEOU) on Perceived Usefulness (PU) is 2.622 with probability of 0.009 or below 0.05 . This means Perceived Ease of Use (PEOU) has a significant effect on Perceived Usefulness (PU).

Implications of this study is are in order to improve the Perceived Usefulness of mobile banking services it is need to improve the Perceived Ease of Use of bank customers, such as providing an interface that is easy and simple and useful to enrich customers' intentions to use and leads to actual usage behavior.

\section{Influence of Perceived Ease of Use on Intention to use}

The coefficient of the effect of Perceived Ease of Use (PEOU) on Intention to Use (IU) is 0.206 with probability of 0.033 . That Coefficient indicates that the Perceived Ease of Use (PEOU) has positive effect on Intention to Use (IU). This means that the increase in Perceived Ease of Use (PEOU), will be followed by an increase in Intention to Use (IU), on the contrary, decreased Perceived Ease of Use (PEOU), will be followed by a decrease on Intention to Use (IU), assuming other factors held constant. Statistical t-value result shows that the influence of Perceived Ease of Use (PEOU) on Intention to Use (IU) is 2.133 with probability of 0.033 or below 0.05. This means Perceived Ease of Use (PEOU) has significant effect on Intention to Use (IU).

The implications of this study are the banks should consider these factors of Perceived Ease of Use (PEOU) to increase the likelihood of customers feel comfortable using mobile banking services.

\section{Influence of Perceived Usefulness on Intention to use}

The coefficient of the effect of Perceived Usefulness (PU) variable on Intentions Using (IU) is 0.207 with probability of 0.023 . That Coefficient indicates that the perception of usefulness (PU) variable has positive effect on Intention to Use (IU). This means that an increase in Perceived usefulness (PU), will be followed by an 
increase Intention to Using (IU), on the contrary, decreased Perceived usefulness (PU), will be followed by a decrease on Intention to Use (IU), assuming other factors held constant. Result of Statistical t-value shows the influence of Perceived Usefulness (PU) on Intentions to Use (IU) is 2.266 with probability of 0.023 or below 0.05. This means the Perceived Usefulness (PU) significantly influence the Intention to Use (IU).

The implications of these findings are the banks must understand the Perceived Usefulness (PU) that influence the intention to use or adoption of mobile banking by such free training on the use of mobile banking services, communicating the benefits or usefulness of mobile banking, provides mobile banking manual on the detail and both available online and offline.

\section{CONCLUSION}

The results of this study concluded that the characteristics of customer acceptance or intention to use mobile banking services in Makassar are influenced by the characteristics of the Perceived Usefulness and Perceived Ease of Use variables. Usefulness variable has more dominant influence than Ease of use variables influence on the intention to use. Therefore, to increase the adoption or the intention to use mobile banking services in Makassar, the banks should provide an easy and simple interface and useful to enrich customers' intentions to use and leads to actual usage behavior. Besides the banks should educate customers about the use of mobile banking and continuously communicate about easy to use mobile banking services. The banks should also increase the perception of the usefulness by provide free training on the use of mobile banking services, communicating the benefits or usefulness of mobile banking, provides mobile banking manual on the detail and both available online and offline.

Some of the research limitations are as follow: (a) the research objects is limited to the observation that was conducted within the cross section time range for one single time. It affects the finding related to the causality relationship among the research's variables. (b) The measurement of the research variables uses customers' perception. There will be a trend that the respondents during filling up the questionnaire will always provide good/agree answers which cannot be used to represent the generalization of the research findings. Further research may also consider other research approach such as TAM2, UTAUT or other technology adoption models.

\section{REFERENCES}

[1] Dwivedi, Y. K., Williams, M. D., Venkatesh, V. (2008) Guest editorial: a profile of adoption of Information \& Communication Technologies (ICT) research in the household context. Information Systems Frontiers, 10(4), pp. 385-390.

[2] Suoranta, M. (2003) Adoption of Mobile Banking in Finland. Doctoral dissertation. Jyväskylä University Printing House, Jyväskylä and ER-paino, Lievestuore.

[3] Birch, D., and Young, M. A, (1997) Financial Services and the Internet: What Does Cyberspace Mean for the Financial Services Industry, Internet Research Vol. 7, No. 2, ,pp. 120-128

[4] Lagoutte, V. (1996). The Direct Banking Challenge, Middlesex University England.

[5] Davis, F. D., Bagozzi, R. P., and Warshaw, P. R. (1989). User Acceptance of Computer Technology: A Comparison of Two Theoretical Models, Management Science, 35 (8), pp. 982-1003.

[6] Venkatesh,Viswanath and Davis ,Fred D. (2000). A Theoretical Extension of the Technology Acceptance Model: Four Longitudinal Field. Management Science, Vol. 46, No. 2, pp. 186-204 Published by: INFORMS Stable .

[7] Davis, F. D. (1989). Perceived Usefulness, Perceived Ease Of Use, and User Acceptance of Information Technology, MIS Quarterly, $13,983-1003$

[8] Fishbein, M., and Ajzen, I. (1975). Belief, Attitude, Intention and Behavior: An Introduction to Theory and Rresearch, Reading, MA:Addison-Wesley.

[9.] Ajzen, I. \& Fishbein, M. (1980). Understanding attitudes and predicting social behavior. Englewood Cliffs, NJ: Prentice-Hall.

[10] Ajzen, I. (1991). The theory of planned behavior. Organizational Behavior and Human Decision Processes, 50, pp. 179-211.

[11] Agarwal, R. \& Prasad, J. (1999). Are individual differences Germane to the acceptance of new information technologies?. Decision Sciences, 30(2), 361-391.

[12] Hu PJ, Chau PYK, Sheng ORL, Tam KY (1999). Examining the technology acceptance model using physician acceptance of telemedicine technology. J. Manage. Info. Syst. 16(2): 91-112.

[13] Jackson, C. M., Chow, S., \& Leitch, R. A. (1997). Toward an understanding of the behavioral intention to use an information system. Decision Sciences, 28(2), 357-389.

[14] Venkatesh, V (1999). Creation of favorable user perceptions: Exploring the role of intrinsic motivation. MIS Quarterly, Vol. 23 No. 2 , pp. 239-260

[15] Mathieson,K. (1991) Predicting user intention: Comparing the technology acceptance model with theory of planned behavior, Information Systems Research, vol. 2, no. 3, pp. 173-191.

[16] Yi, M. Y., and Hwang, Y. (2003). Predicting the use of web-based information systems: Self-efficacy, enjoyment, learning goal orientation, and the technology acceptance model. International Journal of Human-Computer Studies, 59(4), $431-449$.

[17.] Venkatesh V., Morris M.G., G.B. Davis, F.D. Davis, (2003), User acceptance of information technology: toward a unified view, MIS Quarterly, vol. 27, no 3, pp. 425-478.

[18] Heijden VD, H (2004), User acceptance of hedonic information systems. MIS Quarterly, 28(4): 695-704.

[19] Wixom, B.H. \& Todd, P.A., (2005), A Theoretical Integration of User Satisfaction and Technology Acceptance. Information Systems Research, 16(1), pp. 85-102.

[20] Park, J., S.J. Yang, and X. Lehto, (2007). Adoption of Mobile Technologies for Chinese Consumers. Journal of Electronic Commerce Research, Vol. 8, No. 3 pp. 196-206.

[21] Adams, D.A., Nelson, R.R. and Todd, P.A. (1992). Perceived usefulness, ease of use, and usage of information technology: a replication. MIS Quarterly, Vol. 16, No. 2, pp 227-247. 
[22] Hendrickson, A.R., Massey, P.D. \& Cronan, T.P., (1993), On the test retest reliability of perceived usefulness and perceived ease of use scales, MIS Quarterly, 17(2), pp. 227-230.

[23] Hendrickson, A.R. and Collins, M.R. (1996), An assessment of structure and causation of IS usage, The Database for Advances in Information Systems, Vol. 27 No. 2, pp. 61-7.

[24] Segars, A.H. \& Grover, V. (1993). Re-examining perceived ease of use and usefulness: a confirmatory factor analysis. MIS Quarterly, 17, pp. 517-525.

[25] Szajna, B. (1994). Software Evaluation and Choice: Predictive Validation of the Technology Acceptance Instrument, MIS Quarterly (18:3), pp 319-324.

[26] Igbaria, M., Guimaraes, T., \& Davis, G. B. (1995). Testing the determinants of microcomputer usage via a structural equation model. Journal of Management Information Systems, 11(4), pp. 87-114.

[27] Moon, J.-W. and Kim, Y.-G. (2001). Extending the TAM for a World-Wide-Web context. Information \& Management, Vol. 38, No. 4, pp 217-230.

[28] Taylor, S. and Todd, P.A. (1995). "Understanding information technology usage: a test of competing models", Information Systems Research, Vol. 6, No. 2, pp 144-176.

[29] Venkatesh,Viswanath and Davis ,Fred D. (2000). “A Theoretical Extension of the Technology Acceptance Model: Four Longitudinal Field”. Management Science, Vol. 46, No. 2, pp. 186-204 Published by: INFORMS Stable .

[30] Venkatesh, V., Speier, C. and Morris, M.G. (2002), User acceptance enablers in individual decision making about technology: toward an integrated model, Decision Sciences, Vol. 33 No. 3, pp. 297-316.

[31] Henderson. R., Divett. M.J., (2003), Perceived usefulness, ease of use and electronic supermarket use, International Journal of Human- Computer Studies 59(3), pp. 383-395.

[32] Lu, J., C.-S. Yu, C. Liu, and J.E. Yao, (2003). Technology Acceptance Model for Wireless Internet, Internet Research, Vol. 13, No. 3 pp. $206-222$

[33] Wu JH, \& Wang SC.(2005). What drives mobile commerce? An empirical evaluation of the revised technology acceptance model. Information \& Management. 42(5) pp. 719-29.

[34] Gu JC, Lee SC, Suh YH (2009). Determinants of behavioral intention to mobile banking, Expert Systems with Applications, 36(9):11605- 11616.

[35] Hsu, CL and Lu, HP (2004) Why do people play on-line games? An extended TAM with social influences and flow experience, Information \& Management, vol. 41, no.7, pp. 853-868.

[36] Yu, J., Ha,I., Choi, M and Rho, J(2005) Extending the TAM for a t-commerce, Information \& Management, vol. 42, no.7, pp. 965976.

[37] Suh, B and Han,I (2003a) The impact of customer trust and perception of security control on the acceptance of electronic commerce, International Journal of Electronic Commerce, vol. 7, no.3, pp. 135-161.

[38] Suh, B and Han,I (2003b), Effect of trust on customer acceptance of internet banking, Electronic Commerce Research and Applications, vol. 1, no.2, pp. 247-263.

[39] Gefen, D. (2003). TAM or Just Plain Habit: A Look at Experienced Online Shoppers. Journal of End User Computing, 15(3).

[40] Lin, J. C. C., \& Lu, H. (2000). Towards an understanding of the behavioural intention to use a web site. International Journal of Information Management, 20(3), 197-208.

[41] Lucas, H.C. \& Spitler, V.K. (1999). Technology use and performance: A field study of broker workstations. Decision Sciences, 30, 291-311.

[42] Hernandez JMC, Mazzon JA (2007). Adoption of internet banking: proposition and implementation of an integrated methodology approach, International J. Bank Mark. 25 (2): pp. 72-88.

[43] Guriting P, Ndubisi NO (2006). Borneo online banking: evaluating customer perceptions and behavioural intention. Manage. Res. News. 29 (1/2), pp. 6-15.

[44] Eriksson K, Kerem K, Nilsson D (2005). Customer acceptance of internet banking in Estonia, Int. J. Bank Mark. 23 (2), pp.200-216.

[45] Wang Y, Wang Y, Lin H, Tang T (2003). Determinants of user acceptance of internet banking: an empirical study. Int. J. Service. Ind. Manage. 14(5), pp. 501-519.

[46] Chen YH, Barnes S (2007). Initial trust and online buyer behaviour. Ind. Manage. Data Syst. 107 (1), pp. 21-36.

[47] Laforet S, Li X (2005). Consumers' attitudes towards online and mobile banking in China. Int. J. Bank Mark. 23 (5): pp. $362-380$.

[48] Polatoglu VN, Ekin S (2001). An empirical investigation of the Turkish consumers' acceptance of internet banking services. International J. Bank Mark. 19(4): pp. 156-165.

[49] Liao Z, Cheung MT (2002). Internet-based e-banking and consumer attitudes: an empirical study. Info. Manage. 39(4): pp. $283-295$.

[50] Venkatesh ,V., Morris MG (2000). Why don't men ever stop to ask for directions? gender, social influence, and their role in technology acceptance and usage behavior. MIS Quarterly, 24(1): pp. 115-139.

[51] Tan M, Teo TSH (2000). "Factors influencing the adoption of internet banking". J. Assoc. Info. Syst. 1(5): pp. 22-38.

[52] Cooper and Emory. (1998). Metode Penelitian Bisnis. $5^{\text {th }}$ edition. Erlangga, Jakarta.

[53] Joreskog, K.G \& Sorbom, Dag (1993). Lisrel 8: Structural Equation Modeling with the Simplis Command Language, Chicago, SSI Inc.

[54] Schumaker, R.E \& Lomax, Richard G. (1996). A beginner's guide to SEM, New Jersey: Lawrence Erlbaum Associates, Inc.

[55] Kerlinger, Fred N., (1995), Asas-asas Penelitian Behavioral, Yogyakarta: Gajah Mada University Press.

[56] Nirwana SK Sitepu, (1994), Analysis Jalur, Bandung: Unit Pelayanan Statistika Jurusan Statistika FMIPA UNPAD.

[57] Moh. Nazir, (1988), Metode Penelitian, Jakarta: Ghalia Indonesia

[58] Succi, M.J. and Walter, Z.D. (1999), Theory of user acceptance of information technologies: an examination of health care professionals, Proceedings of the 32nd Hawaii International Conference on System Sciences (HICSS), pp. 1-7.

[59] Hair, Joseph F., et. al (2006), Multivariate Data Analysis, $6^{\text {th }}$ Ed. New Jersey, Pearson Prentice Hall.

[60] Ghozali, Imam, (2011). Model Persamaan Struktural: Konsep dan Aplikasi dengan Program AMOS 19.0, BPFE Universitas Diponegoro, Semarang.

[61] Lamb, Charles W., et. al (2002). Marketing, South-Western, New Jersey

[62] Kotler, Philip \& Amstrong, Gary (2011). Marketing: an Introduction, $10^{\text {th }}$ ed, Prentice Hall, Pearson Education.

[63] Wood, Stacy L. and Swait . J. (2002). Psychological Indicators of Innovation Adoption:Cross-Classification Based on Need for Cognition and Need for Change. Journal of Consumer Psychology, 12 (1): pp. 1-13.

[64] Griffin, Jill, 1995, Customer Loyalty, How to Earn it; How to Keep It, New York: Lexington Books, The Free Press. 